\title{
Financial Regulatory Reform: A Progress Report
}

\author{
Glenn Hubbard
}

The 2007-09 financial and economic crisis was the result of a lack of effective regulation. The author addresses the problems with regulations in effect at the time of the crisis and offers proposals for regulation reform to address future crises. He notes that reforms should be based on solid principles, including reduction of system risk and contagion and increased transparency to promote investor protection. Any new financial regulatory structure must be able to achieve these goals, while acknowledging and managing trade-offs between enhancing accountability and mitigating systemic risk from contagion. (JEL G01, G18, G28)

Federal Reserve Bank of St. Louis Review, May/June 2013, 95(3), pp. 181-97.

$\mathbf{T}$ he conventional assessment of the 2007-09 financial and economic crisis places blame on a dearth of regulation. That assessment is simplistic at best and entirely inaccurate at worst. The truth is that the financial crisis is the result of a lack of effective regulation. Several themes emerge from the crisis. First, we need more effective regulation. Although we need new regulation in some previously unregulated areas, the crisis has shown that the most precarious sectors of our financial system are those already subject to a great deal of regulationregulation that has proved woefully ineffective. Any call for further reform means that new or revised regulations should be based on solid principles, chief among them the reduction of systemic risk and contagion. Second, we must increase transparency in the financial system to promote investor protection. More information enables the market to price assets, risk, and other relevant inputs more accurately. Much of the recent crisis can be attributed to a lack of critical information (and perhaps, in some cases, misinformation). Third, we must build a financial regulatory structure able to achieve these goals. Finally, we need to acknowledge and manage trade-offs between enhancing accountability for individual institutions and mitigating systemic risk from contagion.

Glenn Hubbard is the dean and the Russell L. Carson Professor of Finance and Economics in the Graduate School of Business and a professor of economics in the Graduate School of Arts and Sciences of Columbia University; he is a research associate at the National Bureau of Economic Research; he is also a director of a regulated financial services firm, MetLife, and has consulted for financial services firms. This article was based on the author's Homer Jones Lecture, "A Roadmap for Financial Regulatory Reform," at the Federal Reserve Bank of St. Louis, April 3, 2013.

○ 2013, The Federal Reserve Bank of St. Louis. The views expressed in this article are those of the author(s) and do not necessarily reflect the views of the Federal Reserve System, the Board of Governors, or the regional Federal Reserve Banks. Articles may be reprinted, reproduced, published, distributed, displayed, and transmitted in their entirety if copyright notice, author name(s), and full citation are included. Abstracts, synopses, and other derivative works may be made only with prior written permission of the Federal Reserve Bank of St. Louis. 


\section{THE CRISIS AND THE REGULATORY RESPONSE}

\section{Severity of the Crisis}

The 2007-09 financial crisis was the most serious such event since the Great Depression. The crisis manifested itself in credit losses, write-downs, liquidity shocks, deflated property values, and a contraction of the real economy. The sharp contraction in U.S. gross domestic product in 2009 can be traced to the adverse effects of the crisis on household consumption and business investments. Costs directly attributable to the crisis include outlays by the federal government, including the Troubled Assets Relief Program (TARP) and the stimulus package passed in February 2009.

In the housing sector, banks took advantage of low interest rates and securitization opportunities to institute relaxed lending standards that drove the boom in mortgage lending from 2001 to 2006. Although the number of households in the United States increased only marginally between 1990 and 2008, the aggregate mortgage debt outstanding more than quadrupled during that same period. Increased borrowing by U.S. households was partially offset by climbing asset prices. However, the period of rising property values came to a close after the second quarter of 2006, with home prices eventually falling by a third by the end of 2008. The burst of the housing bubble virtually eliminated construction and sales activity for a while. The percentage of delinquent mortgages is at an all-time high, and more than 20 percent of all mortgages are in a negative equity position.

The financial crisis of 2007-09 and its continuing aftermath have complex origins, but those origins share a four-letter word: risk. The mispricing of risk-with inflationary consequences for asset prices in the boom, a downward spiral of collapsing asset prices and economic activity in the bust, and contagion in the unwinding - must be central to economic analysis of and policy responses to the crisis. Underlying factors include (i) global saving and investment imbalances that contributed to low real interest rates and risk premia in international capital markets for many years, (ii) excessively expansionary U.S. monetary policy in the years 2003-05, and (iii) significant gaps in regulation in theory and practice. For the purpose of this article, I concentrate on some key weaknesses in regulation and components of regulatory reform related to capital adequacy, resolution processes for insolvent institutions, and the organization of regulation and policies to manage contagion during a financial crisis. 1

\section{Regulatory Goals and Principles}

An obvious opening question in a debate over major regulatory reform is "What problem are we trying to solve?" Observing the discussion leading up to and following the passage of the Dodd-Frank Wall Street Reform and Consumer Protection Act in 2010, that question is tough to answer. For many economists and policymakers concerned about housing finance, the law was largely silent. The focus on lines of business in the so-called Volcker rule appears somewhat disconnected from the painful problems actually experienced during the financial crisis. And, as I argue below, we must decide whether we are more interested in policies to address the likelihood of failure of individual institutions or the likelihood of contagion across assets, markets, and institutions. $\underline{2}$ 
Going a step further, effective regulatory reform can occur only when policymakers take account of fundamental regulatory principles. The most important of these principles is that regulation should reduce systemic risk. Systemic risk is the risk of collapse of an entire system or entire market, exacerbated by links and interdependencies; with systemic risk, the failure of a single entity or cluster of entities can cause a cascading failure. There are at least five externalities particular to financial markets that contribute to systemic risk. First, the spread of speculative information through the market can create the perception that economic difficulties affecting one financial institution will also affect similarly situated firms. Second, customers of failed institutions may subsequently find themselves in a less-friendly market when seeking to redirect their business. Third, considerable interconnectedness exists among the financial institutions participating in modern financial markets, so the failure of one firm can affect many others. Fourth, falling asset prices and resulting liquidity constrictions may create a negative spiral. Fifth, falling asset prices and liquidity crises may cause institutions to become reluctant to extend credit.

Regulation may be legitimately imposed for a variety of other reasons. Disclosure is important for investors' well-being, in view of the potential for an individual investor to undertake a less-than-adequate investigation before making an investment decision. Further, improving the quality of information and the ease with which it is disseminated is important in protecting consumers from instances of unfair, predatory, and fraudulent behavior. Regulation is also useful in mitigating the risk associated with an investor giving funds to an agent with only very limited control over how this investment is directed. Regulation is likewise important for opening up access to the financial markets, permitting new entrants to join established players, and thereby increasing competition. Finally, regulation can be used effectively to limit the influence of moral hazard that arises from state-provided safety nets and, in particular, to ensure that firms and capital suppliers are not permitted to take advantage of taxpayer support and engage in undue risk-taking. $\cdot \frac{3}{}$

A final principle of regulation applies to all the other principles as well: the cost-benefit rule. That is, a regulation should be promulgated only when its benefits outweigh its costs. Furthermore, if different kinds of regulation can achieve the same benefit, the regulation with the least cost should be adopted (a point that may seem obvious, but given recent regulatory actions, bears repeating). $\underline{4}$

\section{REDUCING SYSTEMIC RISK}

Again, the most compelling justification for financial regulation is the need to reduce externalities-particularly systemic risk. I now consider measures to reduce systemic risk across important sectors of the financial system: capital adequacy requirements, the regulation of nonbank institutions, and the resolution process for insolvent financial institutions.

\section{Regulation of Capital}

Historically, capital regulation has been the dominant regulatory mechanism for constrain-

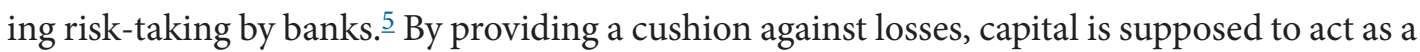


first line of defense against bank failures and their secondary consequences for systemic risk. Yet the existing capital regime-effectively established by the Basel Capital Accords-failed to prevent several of the largest U.S. and European financial institutions from failing or becoming distressed to the point that they required government bailouts. Accordingly, it is important to consider major structural weaknesses in the capital-regulation framework, focusing on institutional coverage, calibration, timing effects, the risks of large institutions, framework design, and capital composition.

Institutional coverage. Until the crisis, it was well understood that firms that were not regulated as banks (or thrifts) and not subject to capital regulation were excluded from the Federal Reserve's safety net. The Fed's emergency measures during the crisis have upended this understanding. These measures may have been justified by the exigencies of the crisis, but they have created structural moral hazards and impediments to a level playing field to the extent that institutions with access to the Fed's safety net are not subject to capital regulation. Looking beyond the crisis, we need to realign the institutional costs and benefits of capital regulation. Institutions with the ability to borrow from the Federal Reserve in its role as the lender of last resort should be subject to some form of capital regulation.

Calibration. Despite the critical role played by capital adequacy in the regulatory framework, existing capital requirements were set without an explicit link to a target standard of solvency for individual banks or for the system as a whole. Though an understandable reaction to the overleveraging of the system would be to raise capital requirements across the board, the lack of empirical research on capital calibration suggests that the costs and benefits of higher capital requirements for banks are uncertain.

Recent arguments (see, for example, Admati et al., 2010) have emphasized that banks cannot simply argue that raising additional equity capital will reduce return on equity and thereby investment in banking. This conclusion arises from the observation that, all else equal, higher levels of bank equity reduce both risk and the costs of leverage. And that conclusion-that riskadjusted return on equity is the more relevant construct-is correct.

From the perspective of economists, the Admati et al. (2010) argument begins with the claim that the differential cost of equity financing relates to the "riskiness" of equity relative to debt (with the attendant claim that if equity is mandated to rise, the cost of loans will rise). Of course, all else equal, if banks held more equity capital relative to risky assets, then the "risk" of equity would fall. Indeed, when the textbook conditions of Modigliani and Miller (1958) hold, banks' overall cost of financing is invariant to leverage. This point is correct (and corroborated by empirical evidence; see, for example, Hanson, Kashyap, and Stein, 2011). It is also, however, a straw man and not a serious contention in the debate over bank equity capital requirements.

The question for economists and regulators is whether the Modigliani-Miller (1958) conditions are a good approximation for the corporate financing environment banks face. An obvious departure from the basic Modigliani-Miller conditions is the presence of corporate taxation of equity returns-specifically, that payments of interest to debt holders are deductible from the corporate tax, while payments of dividends to equity holders are not. If, for example, equity replaced the firm's long-term debt in a bank's capital structure, the bank loses the value of tax deductions of the associated interest payments. 
But, beyond taxes, the Modigliani-Miller (1958) framework faces challenges when applied either to arguments in banking theory or in current bank regulatory discussions about the costs of raising equity capital. Essentially, virtually all of contemporary banking theory-whether based on models of costly state verification, adverse selection, or agency costs-begins with this understanding. And, as I argue below, one cannot assume away equity financing costs related to asymmetric information simply because changes in equity capital arise from regulatory changes.

That costs of asymmetric information raise equity financing costs in banking is uncontroversial to financial economists. The classic "lemons" model of Myers and Majluf (1984) demonstrates adverse selection costs of raising external equity (through underpricing of unobservably healthy banks) or applies more generally to junior securities (say equity as opposed to senior debt); see also Fazzari, Hubbard, and Petersen (1988). Such models calibrate costs of adverse selection in the pricing of an equity offering (or, put differently, in a higher incremental cost of new equity).

Alternatively, equity financing can be modeled as a costly source of new funds because of ex post costs of verification, another type of asymmetric information. Classic models by Diamond (1984) and Gale and Hellwig (1985) demonstrate that banks' use of debt contracts economizes on these costs. $\underline{6}$ Further extensions to models of banking (see, for example, Calomiris and Kahn, 1991, and Diamond and Rajan, 2000) use agency costs to motivate demandable debt contracts for banks supported by bank equity capital. In such models, increases in the ratio of equity to risky assets would raise the cost of equity financing and reduce the volume of bank lending.

It is important to note that costs of equity financing arising from asymmetric information are not eliminated simply because regulation mandates a higher ratio of equity to risky assets. Two points are important here. First, even if all banks were forced to raise equity simultaneously, banks in better condition have an incentive to spend more on underwriting (to give investors that information), raising the cost of new equity. Second, the regulatory change targets the ratio of equity to risky assets. Again, heterogeneity in bank health (known to bank managers, though ex ante not known to potential investors) would generate differences in the degree to which new equity would be raised (with the costs described above) versus shrinking risky assets. Banks in (unobservably) better condition would, all else equal, likely shrink assets to avoid the costly dilution of shareholders (see, for example, Aiyar, Calomiris, and Wieladek, 2012). That is, higher capital requirements applying to all banks do not eliminate costs of adverse selection and, by extension, costs of new equity financing. This second cost would be mitigated to the extent that regulators focused attention on a dollar target for new equity capital, as with the "stress tests" in the United States.

Two categories of empirical research are useful for understanding these arguments. First, many studies have documented the relative costliness of external equity financing $\underline{7}$ and of more junior as opposed to more senior debt claims. ${ }^{8}$ Second, evidence that credit supply responds to a loss of equity capital or to a higher required ratio of equity to risky assets necessarily demonstrates that equity financing is costly. $\underline{9}$

To the extent that bank equity financing is costly, a contraction in bank credit supply is socially costly when there is limited substitutability of bank credit and other funding to some or all borrowers (see the reviews in Hubbard, 1995; Hubbard and O'Brien, 2013; and Hubbard, 
O'Brien, and Rafferty, 2013). Both theoretical and empirical research has highlighted the imperfect substitutability of bank and non-bank sources of funds (for example, securities). Bank lending involves more information-intensive screening and contracting, and many borrowers face high information-related costs in non-bank lending. $\underline{10}$

The flip side of this point is, of course, that if available non-bank sources of funds are relatively close substitutes for bank credit, an increase in bank equity capital requirements will, all else equal, raise the volume of lending in those "close substitute" channels. It is to this link between changes in capital requirements and shadow banking to which I turn below.

Before moving on, it is important to note that the argument that raising bank equity is costless is logically inconsistent with any policy argument for so-called macroprudential capital regulation. For such regulation to be effective, it is necessarily the case that (i) equity financing must be costly relative to other forms of financing and (ii) changes in bank equity capital affect lending (that is, capital requirements are binding and bank and non-bank sources of funds are imperfect substitutes). But, of course, these very factors relate to the social cost of higher capital requirements.

Timing effects. Another feature of the current capital-regulation framework is that minimum capital levels are fixed, while bank losses (or adverse earnings events) vary considerably over the economic cycle. The implication is that solvency standards are not constant during an economic cycle but are dependent on the "state of the world." The solvency level of a given capital requirement depends critically on the period over which it is calibrated and on assumptions of the state of the world going forward. In view of the cyclical nature of bank losses, the effect of a fixed capital requirement is to force banks to raise capital in the downturn as losses mount and capital levels are depleted. A key revision to the existing framework for the regulation of capital adequacy to be studied should be a shift to time-varying capital requirements. An alternative to letting capital requirements fall during a downturn would be to allow-or require-banks to hold some form of contingent capital that can be called upon as losses mount. Countercyclical capital ratios can be achieved in two ways. The first would be to encourage dynamic provisioning. This encouragement could be done without conflicting with existing securities regulation or accounting standards by providing that additional reserves over "known" losses did not run through the income statement but rather constituted a special appropriation of retained earnings. The second way would be to require contingent capital. $\underline{11}$

One mechanism for reducing the cost of higher equity capital is to mandate the use of contingent capital that would increase a bank's equity when some prespecified action occurs. One manifestation, contingent convertibles (see Flannery, 2005, or Calomiris and Herring, 2011), would convert into bank equity if regulatory capital (or in some forms, stock market value) declines below a prespecified value. An alternative manifestation is capital insurance (see Kashyap, Rajan, and Stein, 2008), in which insurance provided by investors would pay off to a bank when a prespecified threshold event occurs.

In contrast to the claims in Admati et al. (2010), contingent capital offers important advantages in a reform to increase bank equity capital. Focusing on higher equity alone cannot fully solve the difficulty of maintaining a desired level of capital. This difficulty arises because the concept of shareholders' equity used in the Basel Accord lags its time value (relying on account- 
ing principles that combine book value, fair value, and market value constructs). As a consequence, regulators must keep pace with financial innovation in security design.

It is, of course, hard for regulators to assess the desired amount of bank equity capital both at a point in time and over time. Well-designed contingent capital requirements can foster incentives for banks to maintain the right amount of capital (in the combination of equity plus contingent capital). Importantly, relative to our earlier discussion of costly equity financing, contingent capital offers a key benefit: Issuing contingent capital need not reduce shareholder value, while mandated equity issues necessarily do so (through both the loss of interest deductions for corporate tax purposes and costs arising from asymmetric information in raising equity).

Calomiris and Herring (2011) suggest market-based measures as a trigger for the conversion of contingent capital (as contingent convertible debt) to equity stock prices. Specifically, they suggest using a 90-day moving average of the ratio of the market value of equity to the sum of the market value of equity and the face value of debt. Given the advantages of contingent capital in mitigating costs of additional equity capital, serious consideration should be given to its design.

Systemically important institutions. The crisis, so far, has disproportionately affected the largest U.S. financial institutions. At the same time, the initial capital injections from the TARP were also concentrated in the largest U.S. banks. Very large banks may pose unique risks to the government because of their systemic consequences. As a result, unless policymakers comprehensively address the problem of too big to fail, one might argue that a large or important bank should be required to hold a larger capital buffer. The flip side of the point is also worth making: To the extent we are willing to let very large banks fail, the high costs of extra capital are less necessary. And, as I argue below, they are very imperfect protection against contagion.

Having said that, certain types of financial institutions generally do not pose systemic risk to the financial system, including asset managers (mutual fund managers, as well as managers of private funds, such as hedge funds and private equity funds) and traditional insurers, since their bankruptcy would not set off a chain reaction of financial institution failures. $\frac{12}{}$

Capital composition. While most of the debate about the Basel framework has focused on the risk assessment of individual banks (which is reflected in the denominator of the Basel capital ratio), the crisis has also raised new concerns about what "counts" as capital in the numerator of the ratio. At present, the regulatory definition of Tier 1 capital is not consistent with tangible common equity, the principal accounting measure of shareholders' exposure to losses. It is also different from Tier 1 common capital, a new definition of capital used in the "stress test." We need a new and consistent definition of capital.

From costly bank equity capital to "shadow banking." The costs of new equity financing I have identified raise concerns about the effects of large increases in equity capital relative to assets on bank lending. For very large banks lending to very large firms with access to non-bank sources of credit, the higher bank cost of financing puts banks at a competitive disadvantage, leading to a search for ways to increase bank leverage. As Hanson, Kashyap, and Stein (2011) point out, there is a pronounced inverse relationship between the ratio of equity to assets and bank size. This search manifests itself, inter alia, in the quest for lending activity outside the regulated banking sector-"shadow banking." And, as I argue below, arguments for macroprudential regulation of bank equity capital requirements extend to more than just deposit-taking banks. 
The experience of the 2007-09 financial crisis offers lessons of the costs of "runs" and financial fragility in the shadow banking system. $\frac{13}{}$ As many economists have emphasized (see particularly Gorton and Metrick, 2012), the collapse of the asset-backed securities market had in common with a textbook bank run the inability of purchasers of asset-backed securities to renew short-term financing.

Mechanically, the bank-run-like removal of short-term lending in shadow banking (the asset-backed securities market) can be understood in the context of "haircuts" in repurchase agreements used to finance conduits holding asset-backed securities in the shadow banking system. A haircut is akin to a down payment constraint, an amount to be posted when an investor borrows in the repo market. Prior to the financial crisis, haircuts on top-rated asset-backed securities were at most 2 percent. In the thick of the crisis, haircuts on both asset-backed securities linked to subprime mortgages and consumer asset-backed securities increased substantially, in some cases to more than 50 percent. This change led to liquidations, further reducing asset prices.

Any change in bank equity capital requirements that does not incorporate the shadow banking system ignores important systemic risk; indeed, it is possible that a substantial increase in capital ratios could increase systemic risk by expanding the shadow banking system. To be effective, such regulation would need to extend to the shadow banking system through regulation of haircuts.

To be specific, consistent capital regulation reform in a macroprudential setting would require that a bank loan or the same holding within an asset-backed security be subject effectively to the same "capital requirement." The case of the loan is straightforward: The asset-backed security holding would have a minimum haircut depending on collateral quality and tranche seniority (see, for example, Geanakoplos, 2010, and Stein, 2012). Such a regulatory approach reduces implicit taxes on bank lending as opposed to shadow bank lending and diminishes the severity of the fire sales in shadow banking.

The alternative to this more-expansive notion of bank capital regulation is to combat runs by extending the federal safety net, as, for example, in the financial crisis. But this policy extends the costly moral hazard built into the current banking safety net, requiring further thought about the pricing of such "insurance."

Back to goals and principles. The most basic arguments for government-mandated capital requirements (as opposed to levels determined by purely market focus) reflect ex ante moral hazard concerns about the regulatory safety net. As I observed above, this ex ante reassurance is not costless. And, more important for reform in the aftermath of the financial crisis, capital requirements cannot be the complete answer in response to the ex post runs by short-term creditors whose investments are exposed to potential fire-sale losses.

\section{Regulation of Non-Bank Financial Institutions}

Hedge funds. Although hedge funds have been around for some 60 years, it was not until the 1990s that these private pools of capital became major players in the global financial markets. Since 1990, assets in the hedge fund industry grew by a factor of more than 12 . By the summer of 2008 , there were about 10,000 hedge funds, with approximately $\$ 2$ trillion under management. 
The key to considering hedge fund regulation is a non-superficial understanding of the role hedge funds play in the global financial markets-an understanding not only of the risks they pose, but also of the risks they mitigate.

The special features of hedge funds have enabled them to both take on risks otherwise borne by traditional financial institutions and bring greater efficiency to the capital markets. On that account, hedge funds have, in fact, contributed to the overall stability of the financial system. Because hedge funds often bet against the market by shorting financial instruments and using other contrarian strategies, they play a major role in reducing the emergence of financial bubbles that may culminate in market instability. Likewise, their active participation in the market for credit derivatives enables them to reduce the risks borne by institutions closer to the center of the financial system. Finally, the arbitrage strategies used by hedge funds and the sheer volume of their trading activity promote greater efficiency in the capital markets.

Nonetheless, some hedge funds may pose a systemic risk to the financial system. A very large, unsustainably leveraged fund exposes a number of large financial institutions to increased counterparty risk. Any effective regulatory regime should aim to curb this systemic risk while enabling the hedge fund industry to continue to provide liquidity, absorb financial risks, and increase the efficiency of the capital markets.

Private equity. Private equity (PE) firms are partnerships that acquire ownership stakes in cash-generative commercial businesses, such as retailers, industrial companies, computer firms, and health care concerns. Because PE firms do not normally borrow, extend credit, serve as derivatives counterparties, or perform other functions normally associated with depository institutions, they could hardly be considered part of the shadow banking system.

To be sure, PE sponsors made greater use of debt to finance deals during the years 2005-07 than they had in previous years, a fact that has caused some analysts to express concern that defaults at PE-sponsored companies will increase in the coming years. Though some defaults have occurred in the difficult macroeconomic environment, these companies have some important advantages relative to their public competitors. Recent research found that during periods of acute financial stress, productivity growth at PE-sponsored companies was significantly higher than productivity growth at comparable non-PE businesses (see Bernstein et al., 2010). In addition, it is important to recognize that the failure of a portfolio company is not likely to have secondary effects on the larger financial system. Portfolio companies are broadly diversified across industries, and neither PE funds nor portfolio companies are cross-collateralized. These factors, taken as a whole, demonstrate that PE firms pose little systemic risk.

Money market mutual funds. Since they began operations in the 1970s, money market mutual funds (MMMFs) have come to play an increasingly important role in the U.S. money markets. Offering a very low-risk, stable investment mechanism for retail investors and large sophisticated investors, MMMFs are also a source of short-term liquidity for the secondary markets. A distinguishing feature of MMMFs is their historically stable share price, usually $\$ 1.00$ per share, which has facilitated their use as cash management devices as an alternative to banks. By law, MMMFs are limited to investing in high-quality, low-risk assets with very short maturities to limit the risks and thereby maintain the stable share price. Despite their low-risk profile, the financial crisis, as it escalated in the wake of the collapse of Lehman Brothers, created 
tremendous instability for money market funds, drying up the flow of short-term liquidity they provided to the market. The Primary Reserve Fund was shown to have been exposed to increasingly risky Lehman Brothers commercial paper that, while giving it the competitive advantage gained from offering higher yields to its investors, nevertheless set the stage for large losses once Lehman Brothers fell. Significantly, as a result of the losses and the rush by investors to redeem their investments, the Primary Reserve Fund "broke the buck," prompting further runs on other MMMFs. As a result of this increasing spread of systemic risk, the Department of the Treasury decided to guarantee the accounts of shareholders in MMMFs existing on the date the guarantee was issued.

The crisis has highlighted the need for reform of the regulatory structure underpinning MMMFs. In particular, MMMFs should adopt better crisis management and more-robust mechanisms for risk monitoring, transparency, and analysis. MMMFs must ultimately be required to compensate taxpayers for the government's guarantees of protection for money market accounts. Returning to the central problem of contagion I raised at the outset, concerns over liquidity remain important. The Securities and Exchange Commission is considering alternatives for restructuring redemptions, an approach opposed strongly by the industry.

Back to goals and principles. From the perspective of systemic risk and contagion, additional regulatory intervention in non-bank financial institutions is difficult to justify. However, assessing liquidity in MMMFs requires further analysis.

\section{Resolution Process for Failed Financial Institutions}

Recent market events have revealed both the strengths and the weaknesses of current insolvency regimes for complex financial institutions. Certain insolvencies have had a far greater systemic effect than others, in part because the law that governs the insolvency of a financial company depends on the company's form of organization. Specifically, the insolvency of banks insured by the Federal Deposit Insurance Corporation (FDIC) is governed by the Federal Deposit Insurance Act (FDIA); the insolvency of registered broker-dealers is governed by the Securities Investor Protection Act; and the insolvency of most other financial companies is governed by the U.S. Bankruptcy Code.

The FDIA enables regulators to more effectively combat systemic risk. Notably, it creates a flexible insolvency regime that provides for pre-resolution action, receivership and conservatorship, and many methods of resolution, including liquidation, open bank assistance, purchase and assumption transactions, and the establishment of bridge banks. This regime has been very successful in promoting stability in the banking system by reducing uncertainty for depositors and counterparties while successfully mitigating losses for banks, counterparties, and the deposit insurance fund. However, the FDIA resolution regime is available only to banks, excluding from coverage many systemically significant financial companies, including bank holding companies. One significant aspect of the FDIA, compared with the Bankruptcy Code, is that it permits the transfer of certain derivatives and other qualified financial contracts to third parties, thus eliminating the downward spiral of prices that can result from a rush to liquidate collateral. A better alternative is to implement a comprehensive Financial Company Resolution Act, applicable to all financial institutions and based on the FDIA, that is applicable to all financial companies. 
The path taken by the Dodd-Frank Act of 2010-the Orderly Liquidation Authority-still leaves many questions unanswered in this regard. Offering a general resolution antidote to too big to fail is particularly important as the legislation's regulatory burdens give an advantage to very large banks relative to smaller banks. And estimates of the value of the funding advantage through an implicit guarantee for very large institutions are in the tens of billions of dollars per year (and, in some estimates, hundreds of billions per year).

Similar national efforts to reform insolvency regimes for complex financial institutions are underway abroad. However, attention also should be paid to the resolution of cross-border financial companies, particularly banks. International working groups at the World Bank, the International Monetary Fund, the Bank for International Settlements, and elsewhere are currently considering various approaches. An effective international framework for resolving cross-border banks would reduce the pressure on national banking regulators to "ring-fence" the assets of a branch or subsidiary of a foreign bank in the event of its insolvency. This work is important and should be supported.

Back to goals and principles. Resolution mechanisms described in this essay, ranging from contingent capital and creditor bail-ins to good-bank/bad-bank structures to Dodd-Frank's Orderly Liquidation Authority, focus on individual institutions. There is still an open question about the extent to which to protect short-term creditors to reduce the likelihood of contagious runs. That is, while ex post resolution mechanisms are specifically designed to force losses on equity and debt holders of failing institutions, those mechanisms may do little to address contagion by exposing short-term creditors to greater risk. I return to this point later.

\section{MINDING THE STORE: REGULATORY STRUCTURE IN THE FUTURE}

\section{An Alternative to the Dodd-Frank Structure}

Effective financial regulation requires a reorganization of the current U.S. regulatory structure. Any decision regarding that structure must be uniquely tailored to the needs of the United States. However, some other major industrial countries have moved toward more consolidated financial oversight. A rapidly dwindling share of the world's financial markets is supervised under the fragmented, sectoral model still used by the United States.

The January 2009 Report of the Committee on Capital Markets Regulation, which I co-chair, summarized appropriate relative responsibilities for the regulatory bodies in a system of consolidated oversight. The Dodd-Frank Act pursued a different path. The Federal Reserve would retain its exclusive control of monetary policy and its lender-of-last-resort function as part of its role in ensuring financial stability. One regulator should have the authority and accountability to regulate matters pertaining to systemic risk.

The Committee on Capital Markets Regulation proposed a new U.S. Financial Services Authority (USFSA) that would regulate all aspects of the financial system, including market structure and safety and soundness for all financial institutions (and possibly consumer and investor protection with respect to financial products if this responsibility were lodged with the USFSA). 
With this approach, the Department of the Treasury would coordinate the work of the regulatory bodies. The Treasury should also be responsible for the expenditure of public funds to provide support to the financial sector. In addition, any existing Fed loans to the private sector that are uncollateralized or insufficiently collateralized should be transferred in an orderly fashion to the balance sheet of the federal government (through asset purchases by the Treasury from the Federal Reserve).

The United States should draw on the experiences of leading jurisdictions in devising a stepby-step regulatory consolidation process. Three options for supervising financial institutions merit serious consideration. The Fed could be placed in charge of supervising financial institutions determined to be "systemically important," and the USFSA could supervise all other institutions. Alternatively, the Fed could be placed in charge of supervising all financial institutions. Finally, the USFSA could be placed in charge of supervising all financial institutions. A vigorous agency for consumer and investor protection could exist as a division within the USFSA. The Dodd-Frank Act of 2010 authorized the creation of a separate agency to be housed within the Federal Reserve.

Most of the issues addressed above reach beyond the borders of any one country. Indeed, the international dimensions of the current financial crisis are so important that it is difficult to characterize this crisis as anything but global. In such an interconnected world, there is a particular need for an effective system of international financial oversight. Such a system should perform three distinct tasks. First, it should build the capacity to harmonize basic global rules. Second, it should serve as an early warning system capable of coordinating swift responses to brewing crises with systemic implications. And third, it should provide some sort of process for efficient dispute resolution when conflicts among regulatory regimes arise.

Though it would be theoretically possible to harmonize financial regulation across borders through international treaties, regulators have instead turned to so-called regulatory networks to deal with the increasing globalization of finance. But these industry-specific networks failed to perform effectively during the recent crisis. Accordingly, the Obama administration and the G-20 have suggested entrusting international regulatory oversight to the Financial Stability Board. A strengthened Financial Stability Board is a good idea, so long as it is flexible and expert enough to harmonize basic rules for the regulation of international finance while still taking a broad view of all the markets in which modern financial conglomerates participate.

Regardless of the multilateral networks and institutions in place, problems are bound to arise when countries pursue different approaches to financial regulation, as evidenced by the war of words in the aftermath of the crisis between the United Kingdom and Iceland over who should take responsibility for failed Icelandic banks doing business in the United Kingdom. Even if some harmonization were successful, issues would still arise when countries pursued different regulations for the same activity. When such conflicts occur, there must be some system for resolving them. In preparation for these expected disagreements, we believe governments ought to strengthen their "regulatory dialogues," if only to maintain open lines of communication among their high-level officials. 


\section{Back to the Problem of Contagion in a Financial Crisis}

In some important ways, recent regulatory reforms have exacerbated problems of systemic risks through contagion. One way costly runs by short-term creditors can be reduced is by lender-of-last-resort support from the central bank. In the teeth of the financial crisis, the Federal Reserve expanded its provision of liquidity through new borrowing facilities. The DoddFrank Act, however, reduced the Fed's lending authority and raised collateral requirements for emergency lending. $\underline{14}$ These limits, particularly given the new power granted to the Secretary of the Treasury, are unlikely to reassure short-term creditors, an essential problem given the fragile maturity transformation inherent in banking. While the law sought to reduce potential taxpayer losses from intervention (in the crisis lending, the Fed actually profited), the trade-off in costs of contagion cannot be ignored.

A second regulatory intervention that makes contagion-fighting more difficult is restrictions on public capital injections. Bailouts were unpopular with much of the public and many policymakers because of ex post taxpayer expense and ex ante moral hazard. That bailouts of automobile companies occurred as well only enhanced public and policymaker concern that such interventions were politically motivated. And there are legitimate fears that such interventions allow politicians to prop up insolvent institutions for an extended period of time. Without guarantee or insurance systems for short-term creditors, however, public capital injections are a potentially valuable tool for addressing contagion and systemic risk during a financial crisis.

What, then, should the United States do in the event of another significant financial crisis? Even if the government lacks standing authority to inject capital, Congress should be prepared to act early during the crisis in the context of a comprehensive plan of action. And the government should increase accountability for equity holders and management. Analyzing ways to resolve competing goals of institutional accountability and preventing contagion should rise in importance in both economic research and policy design—both for commercial banking and shadow banking.

\section{AND THEN THERE WERE NONE}

In Agatha Christie's novel, And Then There Were None, a murder in a grand mansion startles the remaining guests, who then calm down until another murder occurs. And another, and another...As I write this essay, in early 2013, both Washington and Wall Street have slipped into complacency. The case for financial regulatory reform I have outlined here remains strong, and the basic building blocks of regulatory reform appear in many thoughtful proposals for change around the world.

The time for rethinking financial regulatory reform is now. But now is also the time for serious thinking and analysis. What is needed is a clear plan for reducing systemic risk, enhancing transparency, and modernizing regulatory institutions. Despite its 2,300 pages, the DoddFrank Act of 2010 offers as many questions as answers, guaranteeing — not ending - a vigorous debate over the proper scope of financial regulation in the years to come. 
That debate requires us to confront systemic risk and contagion. It also requires us to evaluate trade-offs between mitigating failure of individual institutions versus reducing systemic risk. Finance and the financial system are valuable for savers and borrowers and for the provision of risk-sharing, liquidity, and information services. Proper regulation can preserve and enhance this value.

\section{NOTES}

1 In another essay (Hubbard, 2011), I tackled policy questions related to credit default swaps, securitization, and regulatory structure. I also draw on that essay's points in this lecture.

2 Much of the early policy discussion in the aftermath of the Lehman failure and the AIG rescue concerned interconnectedness of assets and/or liabilities. While such interconnectedness has not been conclusively demonstrated, the problem of contagion - particularly arising from reliance on short-term borrowings by both bank and non-bank institutions-was very important.

3 The Report by the Committee on Capital Markets Regulation enumerated 57 recommendations for reform. The broad principles I outline are similar to those proposed by the Group of 30 in Financial Reform (January 2009; http://fic. wharton.upenn.edu/fic/policy\%20page/G30Report.pdf) and by the Group of 20 in Enhancing Sound Regulation and Strengthening Transparency (March 2009; http://rbidocs.rbi.org.in/rdocs/PublicationReport/Pdfs/20 010409.pdf). The appendix to the Report summarizes similarities and differences in leading proposals for financial regulatory reform.

4 Cost-benefit analysis also is recognized in the Congressional Oversight Panel's Special Report on Regulatory Reform (January 2009; https://www.un.org/ga/president/63/commission/regulatoryreform.pdf) and in the Counterparty Risk Management Policy Group III's report, Containing Systemic Risk: The Road to Reform (August 2008; http://www.crmpolicygroup.org/docs/CRMPG-III.pdf).

$\underline{5}$ See, for example, chapters 10, 11, and 12 of Hubbard and O'Brien (2013).

$\underline{6}$ In much of this research (see especially Diamond, 1984, and Boyd and Prescott, 1986), intermediaries offer low-cost means of monitoring some classes of borrowers. Because of informational frictions, nonmonitored finance entails deadweight spending resources on monitoring. A free-rider problem emerges, however, in public markets with a large number of creditors. The problem is mitigated by having a financial intermediary hold the loans and act as a delegated monitor. Potential agency problems at the intermediary level are reduced by having the intermediary hold a diversified loan portfolio financed principally by publicly issued debt. This line of research argues rigorously that borrowers for whom monitoring costs are significant will be dependent on intermediaries for external finance.

$\underline{7}$ Costly external financing is an important element in contemporary macroeconomic models identifying financial factors in propagating relatively small shocks, factors that correspond to "accelerator" models that explain investment data relatively well. Three common empirical implications have merged from these models (see, for example, Townsend, 1979; Blinder and Stiglitz, 1983; Farmer, 1985; Williamson, 1987; Bernanke and Gertler, 1989, 1990; Calomiris and Hubbard, 1990; Hubbard and Kashyap, 1992; Kiyotaki and Moore, 1997; Greenwald and Stiglitz, 1993; Fazzari, Hubbard, and Petersen, 1988; and Bernanke, Gertler, and Gilchrist, 1996). The first is that uncollateralized external finance is more expensive than internal finance. Second, the spread between the cost of external and internal finance varies inversely with the borrower's net worth relative to the amount of funds required. Third, an adverse shock to a borrower's net worth increases the cost of external finance and decreases the ability of the borrower to implement investment and production plans.

$\underline{8}$ For debt financing, see, for example, James (1987). Ediz, Michael, and Perraudin (1998) find that U.K. banks face lower costs of Tier 2 capital than equity capital.

9 A substantial body of empirical work has studied bank capital crunches to examine links between adverse shocks to bank equity capital and bank lending. See, for example, Bernanke (1983), Bernanke and Lown (1991), Kashyap and Stein (1995, 2000), Peek and Rosengren (1997, 2000), Calomiris and Mason (2003), and Hubbard, Kuttner, and Palia (2002). Other analysis has focused on links between higher bank equity capital requirements and bank lending contraction. See, for example, Furlong (1992), Peek and Rosengren (1995a,b), and Lown and Peristiani (1996).

Using panel data on U.K. banks over the 1996-2007 period, Francis and Osborne (2009) estimate a long-run internal target for the ratio of capital to risky assets. They find that, all else equal, deficits of capital relative to this target have 
lower growth in credit. Using their estimated effects, imposing three 1-percentage-point increases in capital requirements in 1997, 2001, and 2003 would have reduced the stock of lending by more than 5 percent by 2007.

10 A substantial body of empirical evidence supports the idea that banks offer special services in the lending process. For example, James (1987) and Lummer and McConnell (1989) find that the announcement of a bank loan, all else equal, raises the share price of the borrowing firm, likely reflecting the information content of the bank's assessment. In a similar spirit, Fama (1985) and James (1987) find that banks' borrowers, rather than banks' depositors, bear the incidence of reserve requirements (indicating that borrowers must not have easy access to other sources of funds). Petersen and Rajan (1994) show that small businesses tend to rely on local banks for external funds.

11 This recommendation is broadly similar to reforms proposed by the Congressional Oversight Panel in its Special Report on Regulatory Reform (January 2009; see endnote 4), the United Kingdom's Financial Services Authority in The Turner Review: A Regulatory Response to the Global Banking Crisis (March 2009; http://www.fsa.gov.uk/pubs/other/ turner review.pdf), the Group of Thirty in Financial Reform (January 2009; see endnote 3), and the Financial Stability Forum in its Report on Enhancing Market and Institutional Resilience (October 2008; http://www.financialstabilityboard.org/publications/r 0810.pdf). The recommendation that large institutions be held to a higher solvency standard is broadly similar to reforms proposed by the Council on Foreign Relations in the Special Report on Reforming Capital Requirements for Financial Institutions (April 2009; http://www.cfr.org/economics/reforming-capital-requirements-financial-institutions/p19001) and by the Congressional Oversight Panel in Regulatory Reform (January 2009).

12 The Dodd-Frank Act sets forth a $\$ 50$ billion threshold for subjecting bank holding companies to enhanced prudential standards. In the spirit of treating systemically important banks and non-banks similarly, the decision by the Financial Stability Oversight Council (FSOC) to use a bright-line asset threshold for non-bank systemically important financial institution (SIFI) determinations is also a good one. However, for non-banks that meet the Stage 1 \$50 billion threshold, the FSOC should reconsider excluding the categories of institutions I mentioned earlier from SIFI designation.

13 As noted earlier, asset contraction shrinks financing for investment and working capital, leading to a decline in output. Asset contraction across banks can lead to fire sales of assets as banks scramble to raise capital. Such fire sales, as Stein (2012) observes, create an externality: A given bank does not take into account the effect of its own leverage decisions on collateral values of other banks' assets and their ability to raise financing.

14 In addition, the Department of the Treasury cannot guarantee MMMF investors against runs, nor can the FDIC insure senior bank debt without specific congressional approval.

\section{REFERENCES}

Admati, Anat R.; DeMarzo, Peter M.; Hellwig, Martin F. and Pfleiderer, Paul. “Fallacies, Irrelevant Facts, and Myths in the Discussion of Capital Regulation: Why Bank Equity Is Not Expensive." Working paper, Rock Center for Corporate Governance, Stanford University, 2010; updated March 23, 2011; https://gsbapps.stanford.edu/researchpapers/library/RP2065R1\&86.pdf.

Aiyar, Shekhar; Calomiris, Charles W. and Wieladek, Tomas Z. “Does Macro-Pru Leak? Evidence from a U.K. Policy Experiment." NBER Working Paper No. 17822, National Bureau of Economic Research, February 2012; http://www.nber.org/papers/w17822.pdf.?new_window=1.

Bernanke, Ben S. "Non-Monetary Effects of the Financial Crisis in the Propagation of the Great Depression." American Economic Review, June 1983, 73(3), pp. 257-76; http://fraser.stlouisfed.org/docs/meltzer/bernon83.pdf.

Bernanke, Ben S. and Gertler, Mark L. "Agency Cost, Net Worth, and Business Fluctuations," American Economic Review March 1989, 79(1), pp. 14-31.

Bernanke, Ben S. and Gertler, Mark L. "Financial Fragility and Economic Performance." Quarterly Journal of Economics, February 1990, 105(1), pp. 87-114.

Bernanke, Ben S.; Gertler, Mark L. and Gilchrist, Simon. "The Financial Accelerator and the Flight to Quality." Review of Economics and Statistics, February 1996, 78(1), pp. 1-14.

Bernanke, Ben S. and Lown, Cara S. "The Credit Crunch." Brookings Papers on Economic Activity, 1991, 2, pp. $205-39$.

Bernstein, Shai; Lerner, Josh; Sorensen, Morten and Strömberg, Per. "Private Equity and Industry Performance." Harvard Business School Entrepreneurial Management Working Paper No. 10-045, March 2010. 


\section{Hubbard}

Blinder, Alan S. and Stiglitz, Joseph E. "Money, Credit Constraints, and Economic Activity." American Economic Review, May 1983, 73(2), pp. 297-302.

Boyd, John H. and Prescott, Edward. "Financial Intermediary-Coalitions." Journal of Economic Theory, April 1986, 38(2), pp. 211-32.

Calomiris, Charles W. and Herring, Richard J. "Why and How to Design a Contingent Convertible Debt Requirement." Working paper, Columbia Business School, April 2011, revised November 2011; http://www1.gsb.columbia.edu/mygsb/faculty/research/pubfiles/5631/contingent convertible debt.pdf.

Calomiris, Charles W. and Hubbard, R. Glenn. "Firm Heterogeneity, Internal Finance, and 'Credit Rationing."' Economic Journal, March 1990, 100(399), pp. 90-104.

Calomiris, Charles W. and Kahn, Charles M. "The Role of Demandable Debt in Structuring Optimal Banking Arrangements." American Economic Review, June 1991, 81(3), pp. 497-513.

Calomiris, Charles W. and Mason, Joseph R. "Consequences of Bank Distress During the Great Depression." American Economic Review, June 2003, 93(3) pp. 937-47.

Diamond, Douglas W. "Financial Intermediation and Delegated Monitoring." Review of Economic Studies, July 1984, 51(3), pp. 393-414.

Diamond, Douglas W. and Rajan, Raghuram G. "A Theory of Bank Capital." Journal of Finance, December 2000, 55(6), pp. 2431-65.

Ediz, Tolga; Michael, Ian and Perraudin, William. "The Impact of Capital Requirements on U.K. Bank Behaviour." Federal Reserve Bank of New York Economic Policy Review, October 1998, 4(3), pp. 15-22; http://www.ny.frb.org/research/epr/98v04n3/9810ediz.pdf.

Fama, Eugene F. “What's Different About Banks?" Journal of Monetary Economics, January 1985, 15(1), pp. $29-39$.

Farmer, Roger E.A. "Implicit Contracts with Asymmetric Information and Bankruptcy: The Effect of Interest Rates on Layoffs." Review of Economic Studies, July 1985, 52(3), pp. 427-42.

Fazzari, Steven M.; Hubbard, R. Glenn and Petersen, Bruce C. "Financing Constraints and Corporate Investment." Brookings Papers on Economic Activity, 1988, 1, pp. 141-95.

Flannery, Mark J. "No Pain, No Gain? Effecting Market Discipline via 'Reverse Convertible Debentures,"' in Hal S. Scott, ed., Capital Adequacy Beyond Basel: Banking, Securities, and Insurance. New York: Oxford University Press, 2005, pp. 171-96.

Francis, William B. and Osborne, Matthew. "Bank Regulation, Capital and Credit Supply: Measuring the Impact of Prudential Standards." Occasional Paper Series No. 36, U.K. Financial Services Authority, September 2009; http://www.fsa.gov.uk/pubs/occpapers/op36.pdf.

Francis, William B. and Osborne, Matthew. "On the Behavior and Determinants of Risk-Based Capital Ratios: Revisiting the Evidence from U.K. Banking Institutions." International Review of Finance, December 2010, 10(4), pp. 485-518.

Furlong, Frederick T. "Capital Regulation and Bank Lending." Federal Reserve Bank of San Francisco Economic Review, 1992, No. 3, pp. 23-33; http://www.frbsf.org/publications/economics/review/1992/92-3 23-33.pdf.

Gale, Douglas and Hellwig, Martin. "Incentive-Compatible Debt Contracts: The One-Period Problem." Review of Economic Studies, October 1985, 52(4), pp. 647-63.

Geanakoplos, John. "The Leverage Cycle." Cowles Foundation Discussion Paper No. 1715R, Cowles Foundation for Research in Economics, Yale University, July 2009, revised 2010; http://cowles.econ.yale.edu/P/cd/d17a/d1715-r.pdf.

Gorton, Gary B. and Metrick, Andrew. "Securitized Banking and the Run on the Repo." Journal of Financial Economics, June 2012, 104(3), pp. 425-51; http://www.sciencedirect.com/science/article/pii/S0304405X1100081X.

Greenwald, Bruce C. and Stiglitz, Joseph E. "Financial Market Imperfections and Business Cycles." Quarterly Journal of Economics, February 1993, 108(1), pp. 77-114.

Hanson, Samuel; Kashyap, Anil K. and Stein, Jeremy C. "A Macroprudential Approach to Financial Regulation." Journal of Economic Perspectives, Winter 2011, 25(1), pp. 3-28.

Hubbard, R. Glenn. "Is There a 'Credit Channel' for Monetary Policy?" Federal Reserve Bank of St. Louis Review, May/ June 1995, 77(3), pp. 63-77; http://research.stlouisfed.org/publications/review/95/05/Credit May_June1995.pdf. 
Hubbard, R. Glenn. “The Morning After: A Road Map for Financial Regulatory Reform," in Roger B. Porter, Robert R. Glauber, and Thomas J. Healey, eds., New Directions in Financial Services Regulation. Cambridge, MA: MIT Press, 2011, pp. 77-98.

Hubbard, R. Glenn and Kashyap, Anil K. "Internal Net Worth and the Investment Process: An Application to U.S. Agriculture." Journal of Political Economy, June 1992, 100(3), pp. 506-34.

Hubbard, R. Glenn; Kuttner, Kenneth N. and Palia, Darius N. "Are There Bank Effects in Borrowers' Costs of Funds? Evidence from a Matched Sample of Borrowers and Banks." Journal of Business, October 2002, 75(5), pp. 559-81.

Hubbard, R. Glenn and O'Brien, Anthony P. Money, Banking, and the Financial System. Second Edition. Upper Saddle River, NJ: Prentice Hall, 2013.

Hubbard, R. Glenn; O'Brien, Anthony P. and Rafferty, Matthew. Macroeconomics. Second Edition. Upper Saddle River, NJ: Prentice-Hall, 2013.

James, Christopher. "Some Evidence on the Uniqueness of Bank Loans." Journal of Financial Economics, December 1987, 19(2), pp. 217-35.

Kashyap, Anil K.; Rajan, Raghuram G. and. Stein, Jeremy C. "Rethinking Capital Regulation," in Maintaining Stability in a Changing Financial System. Proceedings of the 2008 Jackson Hole Economic Policy Symposium, Jackson Hole, Wyoming, August 21-23, 2008. Kansas City, MO: Federal Reserve Bank of Kansas City, 2008, pp. 431-71; http://www.kc.frb.org/publicat/sympos/2008/KashyapRajanStein.08.08.08.pdf.

Kashyap, Anil K. and Stein, Jeremy C. "The Impact of Monetary Policy on Bank Balance Sheets." Carnegie-Rochester Conference Series on Public Policy, June 1997, 42(1), pp. 151-95.

Kashyap, Anil K. and Stein, Jeremy C. "What Do a Million Observations on Banks Say about the Transmission Mechanism of Monetary Policy?" American Economic Review, June 2000, 90(3), pp. 407-28.

Kiyotaki, Nobuhiro and Moore, John. “Credit Cycles." Journal of Political Economy, April 1997, 105(2), pp. 211-48.

Lown, Cara, and Peristiani, Stavros. "The Behavior of Consumer Loan Rates During the 1990 Credit Slowdown." Journal of Banking and Finance, December 1996, 20(10), pp. 1673-94.

Lummer, Scott and McConnell, John. "Further Evidence on the Bank Lending Process and Capital Market Response to Bank Loan Agreements." Journal of Financial Economics, November 1989, 25(1), pp. 99-122.

Modigliani, Franco and Miller, Merton H. "The Cost of Capital, Corporation Finance and the Theory of Investment." American Economic Review, June 1958, 48(3), pp. 261-97.

Myers, Stewart C. and Majluf, Nicholas S. "Corporate Financing and Investment Decisions When Firms Have Information That Investors Do Not Have." Journal of Financial Economics, June 1984, 13(2), pp. 187-222.

Peek, Joe and Rosengren, Eric S. “Bank Regulation and the Credit Crunch." Journal of Banking and Finance, June 1995a, 19(3-4), pp. 679-92.

Peek, Joe and Rosengren, Eric S. "The Capital Crunch: Neither a Borrower Nor a Lender Be." Journal of Money, Credit, and Banking, August 1995b, 27(3), pp. 625-38.

Peek, Joe and Rosengren, Eric S. "The International Transmission of Financial Shocks: The Case of Japan." American Economic Review, September 1997, 87(4), pp. 495-505.

Peek, Joe and Rosengren, Eric S. "Collateral Damage: Effects of the Japanese Bank Crisis on Real Activity in the United States." American Economic Review, March 2000, 90(1), pp. 30-45.

Petersen, Mitchell A. and Rajan, Raghuram G. "The Benefits of Lending Relationships: Evidence from Small Business Data." Journal of Finance, March 1994, 49(1), pp. 3-37.

Stein, Jeremy. "Monetary Policy as Financial-Stability Regulation." Quarterly Journal of Economics, February 2012, 127(1), pp. 57-95.

Townsend, Robert. "Optimal Contracts and Competitive Markets with Costly State Verification." Journal of Economic Theory, October 1979, 21(2), pp. 265-93.

Williamson, Stephen D. "Costly Monitoring, Optimal Contracts, and Equilibrium Credit Rationing." Quarterly Journal of Economics, February 1987, 102(1), pp. 135-46. 
Hubbard 
